\title{
Queer Space, Pride, and Shame in Moscow
}

\author{
Francesca Stella
}

In urban studies literature, post-Soviet Moscow is classified as an emerging global city, on the ground that the Russian capital has become increasingly integrated into the global economy, acting as a gateway to Russia and the former Soviet region for foreign business and capitalizing on its role as an administrative and political center. ${ }^{1}$ Thus analyses of Moscow as a global city have generally focused on its growing international importance as a wellconnected economic and political center, with much less attention being given to the city's global cultural profile, or to how it manages multicultural diversity. ${ }^{2}$ Yet it has been proposed that policies supportive of multiculturalism and a cosmopolitan outlook, understood as a "receptive and open attitude toward the other," are key characteristics of a successful global city. ${ }^{3}$ Indeed, the active fostering of multicultural diversity as a form of cultural capital is widely explored in the literature on global cities: cultural diversity, produced by postcolonial migration and by the presence of visible subcultural spaces, is celebrated as part of the global city's identity, often through a conscious branding exercise designed to boost the city's cosmopolitan image and to appeal to tourists, who consume the global city as a multicultural spectacle. ${ }^{4}$

Examined here is the notion of Moscow as a global city through the prism of cultural diversity and cosmopolitanism; specifically, the article explores articulations of queer space in the Russian capital, defined here as space occupied (temporarily or permanently) by the lesbian, gay, bisexual, and transgender (LGBT) community as a subcultural group. ${ }^{5} \mathrm{I}$ am interested in how dif-

Work on this article was supported by the Economic and Social Research Council (grant ES/I038497/1). I also gratefully acknowledge funding for the original fieldwork from the Carnegie Trust from the University of Scotland, the British Association for Slavonic and East European Studies, and the Centre for Russian, Central and East European Studies, University of Glasgow. I would also like to thank Mark D. Steinberg, Sarah Hudspith, and the anonymous reviewers for Slavic Review for their very helpful and constructive comments on the original manuscript.

1. Isolde Brade and Robert Rudolph, "Moscow, the Global City? The Position of the Russian Capital within the European System of Metropolitan Areas," Area 36, no. 1 (March 2004): 69-80.

2. For an exception see Cordula Gdaniec, ed., Cultural Diversity in Russian Cities: The Urban Landscape in the Post-Soviet Era (Oxford, 2010).

3. Gavin Kendall, Ian Woodward, and Zlatko Skrbiš, The Sociology of Cosmopolitanism: Globalization, Identity, Culture and Government (Basingstoke, Eng., 2009), 1.

4. Mark Abrahamson, Global Cities (Oxford, 2004); Ulf Hannerz, "The Cultural Role of World Cities," in Neil Brenner and Roger Keil, eds., The Global Cities Reader (New York, 2006), 313-18.

5. Queer is used here as a shorthand, umbrella term encompassing the whole range of nonheterosexual and nongender binary sexual and gender identities. The gender-neutral term queer is used to refer to space collectively occupied by nonheterosexual men and women, although gender-specific terms such as gay or lesbian will be used where appropriate. On the definition of queer space, see Natalie Oswin, "Critical Geographies and the 
ferent sections of the Moscow LGBT community, like other minority groups, "carve their own, separate spaces within the city, construct urban niches for themselves, and negotiate visibility or rights." Visibility, rather than rights, is my thematic focus, as I explore the construction and perception of different kinds of queer space in Moscow. First, drawing on the findings of an ethnographic study on lesbian identity and everyday spaces in urban Russia (2004-2005), I examine perceptions of Moscow as a multicultural and "queerfriendly" city among lesbian and bisexual women living in the capital and in the provincial city of Ul'ianovsk and survey the geography and relative visibility of queer spaces in Moscow. Ethnographic data is used as a foil to consider how the annual organization of Moscow Pride (2006-present) changed the articulation of queer space in Moscow by explicitly politicizing the appropriation of city space as queer, and by giving the parade unprecedented visibility and media exposure, both nationally and internationally.

Moscow Pride was repeatedly banned by the Moscow authorities and marred by homophobic violence, and the mainly hostile reactions to it projected an image of the Russian capital as "one of the least gay-friendly cities in Europe" and therefore a most uncosmopolitan place. ${ }^{7}$ The ban highlights the extent of institutionalized homophobic prejudice in Russia, and it is easy to read the controversies around Moscow Pride in oppositional terms, pitting the sexual liberalism of queer activists against the sexual fundamentalism of local authorities. Yet, a holistic analysis of queer space in Moscow problematizes the notion of visibility as empowering and shows the limitations of political strategies based on claims to visibility and rights that are well received internationally but enjoy little support locally. The article critically examines the notion of queer visibility embodied by Moscow Pride as a "putative cosmopolitan object," understood here as an object whose international proliferation is deemed to be a product of globalization and a progressive marker of cultural diversity and social justice, but "whose interpretation and use within cosmopolitan frames of social action" in a given local context is not guaranteed. ${ }^{8}$

\section{Cosmopolitanism and Queer Space: A View from Moscow}

Cosmopolitanism is here defined as "a way of relating to the world" based on openness and respect toward diversity and on the premise of overcoming particularistic ties to kinship, local communities, and the nation in order to em-

Uses of Sexuality: Deconstructing Queer Space," Progress in Human Geography 32, no. 1 (February 2008): 89-103.

6. Cordula Gdaniec, "Cultural Diversity between Staging and the Everyday-Experiences from Moscow, St. Petersburg and Other Russian Cities: An Introduction," in Gdaniec, ed., Cultural Diversity in Russian Cities, 3.

7. Shaun Walker, "Sacked Journalist puts Spotlight on Russia's Gay Pride March Ban," The Independent, 26 July 2011, at www.independent.co.uk/news/world/europe/ sacked-journalist-puts-spotlight-on-russias-gay-pride-march-ban-2325953.html (last accessed 31 May 2013).

8. Kendall, Woodward, and Skrbiš, Sociology of Cosmopolitanism, 124, 125. 
brace universal values of pluralism and multicultural inclusiveness. ${ }^{9}$ It has been suggested that cosmopolitanism is the positive face of globalization, as the "time-space compression" engendered by the latter opened up new opportunities, not only for neoliberal capitalism, but also for spreading democratic values through transnational institutions and social movements. ${ }^{10}$ Moreover, cities have traditionally been considered privileged cosmopolitan locations because of the diversity they embody, and it has been proposed that the celebration of this multicultural diversity as a form of cultural capital is a key attribute of global, outward-looking cities.

As Cordula Gdaniec notes, however, although all cities are multicultural and diverse, not all actively celebrate diversity: for example, unlike other European cities such as Berlin, the Moscow administration has been reluctant to promote multicultural diversity as a resource that can be successfully drawn upon to generate political and economic clout for the city. ${ }^{11}$ Gdaniec's own research shows how minority ethnic groups have had an uneasy relationship with the authorities in post-Soviet Moscow: previously cultivating a multicultural image as the capital of the multinational and internationalist Soviet Union, the city is increasingly constructed as "Slavic" and Russian, and selective gestures toward multicultural inclusion have been contradicted by evidence of institutional prejudice and by a surge in the number of racially motivated crimes. ${ }^{12} \mathrm{Gdaniec}$ 's insight invites a critical engagement with the notion of cosmopolitanism as the inevitable product of globalizing processes.

Gdaniec also emphasizes the difference between western European cities, where multiculturalism is mainstreamed in policy and cultural diversity is marketed as an asset, and Russian cities, which have so far largely failed to implement policies promoting cultural diversity. ${ }^{13}$ Other scholars, though, have been critical of the assumption that cosmopolitanism is always a progressive force, striving to promote a meaningful engagement with, and acceptance of, the "other." For example, Slavoj Žižek has famously critiqued multiculturalism for allowing a very superficial engagement with difference through commodification and consumer practices without fundamentally challenging social exclusion. ${ }^{14}$ While the differences Gdaniec outlines between Moscow and Berlin reflect different institutional attitudes toward multicultural policies, all cities face many common challenges in dealing with issues of diversity and equality, and these challenges are far from having been resolved in "western" cities.

This article engages with the notion of "sexual cosmopolitanism," defined

9. Eduardo Mendieta, "From Imperial to Dialogic Cosmopolitanism?" Ethics and Global Politics 2, no. 3 (2009): 242.

10. David Harvey, The Condition of Postmodernity: An Enquiry into the Origin of Cultural Change (Oxford, 1990); see also Anthony Giddens, Runaway World: How Globalisation Is Reshaping Our Lives (London, 2000); Daniele Archibugi and Daniel Held, eds., Cosmopolitan Democracy: An Agenda for a New World Order (Cambridge, Mass., 1995).

11. Gdaniec, "Cultural Diversity between Staging and the Everyday," 1-20.

12. Ibid.

13. Ibid.

14. Slavoj Žižek, "Multiculturalism, or, the Cultural Logic of Multinational Capitalism," New Left Review, no. 225 (September-October 1997): 28-52. 
as "awareness of, and willingness to live with, human sexual variety both within and across cultures."15 A significant body of literature exists on urbanism, queer space, and cosmopolitanism; most of it focuses on western metropolitan areas, however, while perspectives from provincial and nonwestern urban locales are neglected. ${ }^{16}$ This point resonates with the views of a range of scholars working on postsocialist eastern Europe and the former Soviet Union who have highlighted the limited analytical purchase of theoretical frameworks ultimately based mainly on the experience of liberal western societies and on the value-laden character of theoretical concepts such as "transition" and "democracy"-a list to which "cosmopolitanism" can usefully be added. ${ }^{17}$ In keeping with these premises, my aim is not to attempt to assess whether Moscow's credentials measure up to the purported cosmopolitanism of other western cities; instead, I use empirical research to question ethnocentric assumptions in the theory by examining how queer space in Moscow, understood as a putative cosmopolitan object, is constructed and perceived by different agents at the global, national, and local levels.

I focus on two distinct types of queer space: the "scene," understood as a loose cluster of commercial venues and community organizations catering to an LGBT clientele, as well as more informal locations where queers socialize; and Pride events, understood as a temporary but also highly visible and politicized appropriation of urban space by the LGBT community. Both the scene and Prides can be understood as putative cosmopolitan objects in two respects. First, their visible presence in city space is widely read in the literature on queer space and urbanism as a sign of openness and acceptance toward the sexual "other" and a gesture toward multicultural inclusion;18 in this sense "gay culture occupies a pivotal role within the production and consumption of urban spaces as cosmopolitan."19 Second, both can be read as instances of the transnational proliferation of a recognizable repertoire of queer consumption and politics, an instance of cultural globalization that Dennis Altman dubs "global queering." ${ }^{20}$ Both "scene" space and Prides are putative cosmopolitan objects by virtue of their visibility and transnational

15. Ken Plummer, "Critical Sexualities Studies," in George Ritzer, ed., The WileyBlackwell Companion to Sociology (Malden, Mass., 2012), 248-49.

16. Jon Binnie, The Globalization of Sexuality (London, 2004), 4-5.

17. See, for example, Michael Burawoy and Katherine Verdery, eds., Uncertain Transitions: Ethnographies of Change in the Post-Socialist World (Lanham, Md., 1999); Anna Temkina and Elena Zdravomyslova, "Gender Studies in Post-Soviet Society: Western Frames and Cultural Differences," Studies in East European Thought 55, no. 1 (March 2003): 51-61; Robert Kulpa and Joanna Mizielińska, eds., De-Centring Western Sexualities: Central and Eastern European Perspectives (Farnham, Eng., 2011). For a discussion of cosmopolitanism as a "Babelian tower of discourse," see Mendieta, "From Imperial to Dialogic Cosmopolitanism?" 241-58.

18. Leslie Moran and Beverley Skeggs, with Paul Tryer and Karen Corteen, Sexuality and the Politics of Violence and Safety (London, 2004).

19. Jon Binnie and Beverley Skeggs, "Cosmopolitan Knowledge and the Production and Consumption of Sexualised Space: Manchester's Gay Village," Sociological Review 52, no. 1 (February 2004): 40.

20. Dennis Altman, "On Global Queering," Australian Humanities Review, no. 2 (July 1996), Internet edition at www.australianhumanitiesreview.org/archive/Issue-July-1996/ altman.html (last accessed 31 May 2013). 
readability. Leslie Moran and Beverley Skeggs, for example, note that in western cities the presence of visible and territorialized queer space in gentrified central areas has become invested with political meaning, as "gay villages" are widely read as evidence of the legitimization of queer presence in public space. ${ }^{21}$ Similarly, as Gill Valentine points out, Prides are conceived as a "collective coming out" and are premised on the idea of becoming visible as a key strategy for gaining recognition and challenging societal prejudice..$^{22}$ Originally conceived as protest marches in 1970s America, in many western cities Prides have evolved into colorful street parties intended to celebrate sexual cosmopolitanism. ${ }^{23}$ Yet the notion of queer visibility as empowering and as evidence of societal acceptance is problematic in the Russian context. Anxieties over the new visibility of homosexuality have become intertwined with the crisis and renegotiation of national identity in post-Soviet Russia. ${ }^{24}$ Concerns about the pernicious effects of queer visibility on the fabric of Russian society have become increasingly prominent, and in nationalist discourses queer visibility is explicitly linked to more permissive sexual mores, declining moral values, and western influence. Indeed, as Brian Baer perceptively notes, "the 'global gay' has become a convenient symbol of Western cultural imperialism, involving the encroachment of Western values (overt sexuality, nonreproductive sex, and consumerism) and Western political concepts (tolerance, diversity, and civil rights)." ${ }^{25} \mathrm{~A}$ conservative backlash against queer visibility, which has been brewing since the early 2000 s, has recently resulted in the introduction of legislation against the "propaganda of homosexuality" in four Russian oblasts (Riazan', 2006; Arkhangel'sk, 2011; St. Petersburg, 2012; and Novosibirsk, 2012). ${ }^{26}$ Even more worryingly, the Federal Duma was called to consider the extension of the legislation to the whole of Russia, and at the first reading in January 2013 members of the Duma voted overwhelmingly in favor of the bill (338-1). Although the draft law needs to pass through two more readings in the Duma and be approved by the upper house before being

21. Moran and Skeggs, Sexuality and the Politics of Violence and Safety.

22. Gill Valentine, "Sexual Politics," in John Agnew, Katharyne Mitchell, and Gerard Toal, eds., A Companion to Political Geography (Oxford, 2003), 408-20.

23. See, for example, Steven M. Kates, "Producing and Consuming Gendered Representations: An Interpretation of the Sydney Gay and Lesbian Mardi Gras," Consumption, Markets and Culture 6, no. 1 (January 2003): 5-22; Kath Browne, "A Party with Politics? (Re)making LGBTQ Pride Spaces in Dublin and Brighton," Social and Cultural Geography 8, no. 1 (February 2007): 63-87; Jon Binnie and Christian Klesse, "Because It Was a Bit Like Going to an Adventure Park': The Politics of Hospitality in Transnational Lesbian, Gay, Bisexual, Transgender and Queer Activist Networks," Tourist Studies 11, no. 2 (August 2011): 157-74.

24. Michele Rivkin-Fish, “From 'Demographic Crisis' to 'Dying Nation': The Politics of Language and Reproduction in Russia," in Helena Goscilo and Andrea Lanoux, eds., Gender and National Identity in Twentieth-Century Russian Culture (DeKalb, 2006); Brian James Baer, Other Russias: Homosexuality and the Crisis of Post-Soviet Identity (Basingstoke, Eng., 2009); Dan Healey, "Active, Passive, and Russian: The National Idea in Gay Men's Pornography," Russian Review 69, no. 2 (April 2010): 210-30.

25. Baer, Other Russias, 6.

26. Francesca Stella, "The Right to Be Different? Sexual Citizenship and Its Politics in Post-Soviet Russia," in Rebecca Kay, ed., Gender, Equality and Difference during and after State Socialism (Basingstoke, Eng., 2007). 
signed into law, it is likely that the bill will eventually come into force. ${ }^{27}$ This conservative turn is linked to the resurgence of authoritarian and antiwestern nationalism in Russian political life, a theme considered in the second part of my article.

Since plans to organize a gay Pride in Moscow first emerged in 2005, the event has catalyzed debates on queer visibility and minority rights; indeed, Moscow Pride radically changed the articulation of queer presence and activism, not only in the capital, but in Russia more broadly. Moscow is an interesting focal point from which debates about queer space, nationalism, and cosmopolitanism can be explored because the capital is simultaneously the most international and the most "national" of all Russian cities. As Vanessa Rampton and Muireann Maguire write, the notion of "center" and "periphery" have traditionally been central to Russian intellectual debates on the country's development and international role; these debates have two dimensions, "the traditional dominance of Russia's value-generating administrative capital over the country's 'unruly periphery,' on the one hand, and the question of Russia's 'marginality' to a civilizational center located in western Europe and the United States, on the other."28 These debates have traditionally marked Moscow as exceptional, as the symbolic heart of the nation and of a strong centralized state and as a postsocialist global city whose economic development, living standards, and central role in setting cultural trends set it apart from the rest of Russia.

\section{Queer Moscow before the Pride}

\section{Perceptions of Moscow among Lesbian and Bisexual Women}

Findings from my study on lesbian identity and space in urban Russia show that Moscow was perceived as exceptional vis-à-vis the rest of Russia among lesbian and bisexual women and that the capital was widely considered more dynamic and cosmopolitan compared to provincial Russia, if we understand cosmopolitan to be "an oppositional term evoked against all that is fixed, parochial, especially national."29 The topic of Moscow's exceptionalism often surfaced in interviews, as just over half of the Moscow participants had moved

27. ILGA-Europe, Annual Review of the Human Rights Situation of Lesbian, Gay, Bisexual, Trans and Intersex People in Europe (2011), at www.ilga-europe.org/home/ publications/annual_review/2011 (last accessed 31 May 2013); Steve Gutterman, "Russian Bill Would Impose Fines for Gay 'Propaganda,"' Reuters, 29 March 2012, at www. reuters.com/article/2012/03/29/us-russia-gays-legislation-idUSBRE82S10Y20120329 (last accessed 31 May 2013); "Novosibirsk Region Latest to Pass Anti-Gay Law," Moscow Times, 27 April 2012, at www.themoscowtimes.com/news/article/novosibirsk-region-latest-topass-anti-gay-law/457627.html\#ixzz1tF5VpVPM (last accessed 31 May 2013); "Russian MPs Back 'Gay Propaganda' Ban Amid Scuffles," BBC News, 25 January 2013, at www.bbc. co.uk/news/world-europe-21194710 (last accessed 31 May 2013).

28. Vanessa Rampton and Muireann Maguire, "Introduction: Russia on Edge: Centre and Periphery in Contemporary Russian Culture," Studies in Eastern European Thought 63, no. 2 (June 2011): 89.

29. Binnie and Skeggs, "Cosmopolitan Knowledge and the Production and Consumption of Sexualised Space," 41. 
to the Moscow region from provincial cities and small towns, and many of them explicitly talked about their reasons for moving and compared their experiences of living in different urban environments. ${ }^{30}$ Sveta, a young woman from Ul' ianovsk who had moved to Moscow two years earlier, noted that living in Moscow allowed her and her partner greater freedom and privacy as a lesbian couple. They had moved in together when still living in Ul'ianovsk, but she had experienced a lot of pressure from family members to end the relationship, while the fact that her family was well known in the city had made her feel exposed to constant scrutiny: "Yes, [here in Moscow] it is a lot easier. Ul' ianovsk is a small city, everyone knows each other, and you attract a lot of attention. Over there my parents have prestigious jobs, and so do my brother and a close relative. Everyone was interested in knowing who I was living with, who I was sleeping with. Here, no one needs to know. In this respect things are easier here."

Although Sveta stressed that the decision to move was motivated by better career prospects, rather than by the desire to escape unwanted scrutiny and homophobia, she also remarked on the fact that one of the collateral benefits of moving to Moscow was the ability to remain inconspicuous and anonymous as a lesbian woman. Sveta's experience resonated with those of other interviewees, who acknowledged that moving to Moscow had given them greater anonymity and made them less conspicuous or concerned about societal scrutiny than in the towns and cities where they had grown up. They also noted that in Moscow cultural diversity was more visible, particularly in the city center, the traditional meeting place of youth tusovki, and this diversity made it easier for them to blend in.

The accommodation of cultural diversity, however, was mainly seen as a quality stemming from Moscow's size and busy life, rather than reflecting a more open-minded "cosmopolitan" disposition among its population. Having moved to Moscow from Chel' iabinsk in the mid-1990s, Galia noted that greater exposure to diversity may engender indifference, rather than be a reflection of a more benevolent attitude toward the sexual "other":

In Moscow it is easier, because here there are more opportunities, more activities, and people are more indifferent to one another. In the provinces there is less, and the opinion of one's neighbor is very important. Stereotypes are strong. In Moscow it is easier, but still no teacher would come out as gay or lesbian. The difference in Moscow is not tolerance, but indifference. People are more absorbed by their problems, they have to work, to earn money, to feed their family, while in the provinces public opinion is very

30. The study was based on multisited fieldwork and aimed to compare the experiences of nonheterosexual women from Moscow, a city with a relatively well established gay and lesbian scene, and from Ul'ianovsk, a provincial city of 700,000 in the middle Volga region with no commercial scene or community organizations. Ethnographic fieldwork was conducted in 2004 and 2005; methods of data collection included semistructured, in-depth interviews with 61 nonheterosexual women, aged 18 to 56 (34 living in the Moscow region and 27 in the city of Ul'ianovsk); 7 expert interviews with Moscowbased community activists and entrepreneurs; and participant observation of community events and social gatherings for lesbian and bisexual women. In the interest of preserving anonymity, all names have been changed. 
strong. [. . . I think the difference in Moscow is that people are very distant from each other, and Moscow in this respect is more similar to Europe or America, and people can accept this [homosexuality] simply because it has nothing to do with them. Not because they take this to be of equal worth as heterosexuality.

As Galia noted, while Moscow was generally perceived as a relatively safe and tolerant city, compared to the provinces, lesbian and bisexual women did not necessarily feel free to be "out"; on the contrary, safety and personal comfort were premised on anonymity and on setting and keeping personal boundaries. ${ }^{31}$ She also remarked that Moscow is very different from the rest of Russia, that it is, in some respects, more similar to the "west" (Europe or America). ${ }^{32}$

While some women, like Galia, talked about Moscow exceptionalism in terms of the lifestyle and character of its inhabitants, others related it more explicitly to the presence of relatively visible queer subcultural spaces in the city. The presence of a relatively well developed gay and lesbian scene was part of the capital's allure, and one of the reasons women living in other parts of Russia gave for visiting Moscow. Community organizations such as the Lesbian and Gay Archive, as well as the lesbian club nights at the disco Udar were known to women visiting Moscow from other Russian regions, who visited them as tourist attractions. Moreover, women from the Ul' ianovsk queer tusovka were aware of lesbian community and commercial spaces in Moscow, and some had taken advantage of leisure or business trips to the capital to visit them. The lack of any infrastructure for the local queer tusovka was contrasted to the range of opportunities to socialize offered by bigger, more "civilized" cities, and the Moscow scene often featured in conversation as a term of comparison. Margarita noted that her native Ul'ianovsk did not have any community organizations campaigning for LGBT rights, unlike Moscow, which in this respect she considered "almost the same as abroad [pochti chto zagranitsu]." She also noted that visits to Moscow and other cities also offered the opportunity to

31. Indeed, both in Moscow and in Ul'ianovsk, women played down the importance of being "out" as lesbian or bisexual and the ideals of authenticity and visibility associated with it, remarking instead on the importance of preserving boundaries between areas of their lives where their sexuality could be safely expressed and others where they considered disclosure inappropriate, uncomfortable, or dangerous. Similar findings on attitudes toward coming out among queer-identified young people in Russia emerge from other empirical work; see, for example, Nadezhda Nartova, "Lesbians in Modern Russia: Subjectivity or Soviet Practices of 'Hypocrisy'?" in Mihaela Frunză and Theodora-Eliza Văcărescu, eds., Gender and the (Post) "East"/"West" Divide (Cluj-Napoca, 2004); Elena Omel'chenko, "Izuchaia gomofobiiu: Mekhanizmy iskliucheniia 'drugoi' seksual'nosti v provintsial'noi molodezhnoi srede," in Elena Zdravomyslova and Anna Temkina, eds., V poiskakh seksual'nosti: Sbornik statei (St. Petersburg, 2002).

32. Other research shows that the perception of Moscow as exceptional and distinct from the rest of Russia is widespread, particularly in provincial Russia. See, for example, a survey entitled "Moscow and Muscovites: Facts and Fiction," Pravda, 8 September 2009, at english.pravda.ru/society/stories/08-09-2009/109158-moscow-0/ (last accessed 31 May 2013), and Hilary Pilkington et al., Looking West? Cultural Globalization and Russian Youth Cultures (University Park, 2002), a study on young people and globalization that shows that many young people from provincial Russian cities identified Moscow as a "western" city. 
purchase lesbian-themed books and films that were not available for sale in Ul'ianovsk: "In Moscow I found this book, Moskva, stantsiia Lesbos [Moscow: Lesbos Underground Station]; I saw it in a bookshop. My girlfriend and I went in and asked, do you have any books with a lesbian theme?"33

Women seemed to respond to the allure of Moscow mainly as a hub of queer consumer culture and as a city offering greater opportunities to socialize with like-minded women. In this respect, Moscow was perceived as more "progressive" and cosmopolitan than provincial and rural Russia: the presence of subcultural queer spaces allowed women to transcend pressures to conform to a heteronormative lifestyle and to reimagine Moscow as a space of belonging and freedom. Yet, greater freedom was linked to the possibility to remain inconspicuous as a lesbian or bisexual woman and to the anonymity and privacy granted by living in a big city, rather than to Muscovites' inherently more "progressive" and "cosmopolitan" attitudes toward sexual diversity.

\section{Mapping Queer Space in Moscow}

A vast body of literature on the production and consumption of cosmopolitan queer space has focused on very visible and territorially bound "gay scenes," embodied by "gay villages" in gentrified city center areas. Much has been written, for example, about how gay enclaves such as Marais in Paris or Soho in London, and events such as Sydney's Mardi Gras parade, have been showcased and marketed to promote the host city's cosmopolitan, multicultural, and sophisticated image. ${ }^{34}$ This literature is of limited use as a point of reference, however, as neither visibility nor territorial concentration are a feature of the queer scene in Moscow.

The formation of an institutionalized queer "scene," comprising a loosely intertwined cluster of commercial venues and community organizations catering to the LGBT community, has a relatively recent history in Moscow..$^{35}$ A commercial queer scene did not emerge until the early 1990s, a fact that can be explained not only by Soviet criminalization of male homosexuality and stigmatization of all forms of same-sex desire but also by the lack of a consumer-oriented entertainment industry and by Soviet censorship of public discussion on sexual matters, which delayed the commoditization of sex and sexuality more broadly. By the mid-2000s, Moscow, Russia's biggest and most affluent city, hosted a lively commercial scene, comprising a range of clubs, cafes, and restaurants, as well as the most successful Russian LGBT informa-

33. Margarita Sharapova, Moskva, stantsiia Lesbos: Povesti (Ekaterinburg, 2004). Set in Moscow, this novella centers on the intersecting lives of a group of lesbians and gay men.

34. Alan Collis, "Sexual Dissidence, Enterprise and Assimilation: Bedfellows in Urban Regeneration," Urban Studies 41, no. 9 (August 2004): 1789-806; Denis M. Provencher, Queer French: Globalization, Language, and Sexual Citizenship in France (Burlington, Vt., 2007); Kates, "Producing and Consuming Gendered Representations," 5-22.

35. Dan Healey, Homosexual Desire in Revolutionary Russia: The Regulation of Sexual and Gender Dissent (Chicago, 2001); Laurie Essig, Queer in Russia: A Story of Sex, Self, and the Other (Durham, 1999). 
tion resources, such as the portal gay.ru (founded in 1997) and the glossy magazines Kvir (2004) and Pinx (2006). Moscow also hosts a wide range of nongovernmental organizations (NGOs) and third-sector organizations, and, at the time when my fieldwork took place, there were several lesbian, gay, or LGBT organizations and grassroots initiatives in the city, some well-established and others with a more ephemeral existence.

Although Moscow has an established and well-developed queer scene, territorial concentration is not a feature of commercial and community venues; these are geographically scattered in different districts of Moscow and do not form a recognizable queer enclave. At the time of my fieldwork, some venues, such as the gay and lesbian bar 12 Volts and the LGBT organization Ia + Ia (housed in the same premises as the commercial business gay.ru), were located within the Boulevard Ring in central Moscow, but not in close proximity. Others, such as the club Udar, the Lesbian and Gay Archive, and the Klub Svobodnogo Poseshcheniia, were located in the periphery, outside the Garden Ring or on the very outskirts of Moscow. Other community and commercial initiatives were itinerant, for example, the lesbian concerts organized monthly by the commercial organization Labrys took place at regular intervals, but in different premises hired ad hoc for the occasion from commercial businesses or local authorities.

Moscow's queer scene was not immediately visible and recognizable, a fact that reflects, to some extent, the chaotic character of post-Soviet Moscow's reconstruction and the complex political and economic interests surrounding the gentrification of its inner city. Exercising discretion seemed to be a deliberate strategy to avoid unwanted or hostile attention, however, as a degree of privacy and even secrecy characterized both commercial and community initiatives. Commercial initiatives were more visible than community ones, as their viability and success depended on attracting paying patrons: clubs, bars, and festivals were advertised not only in the gay and lesbian press but also in the "gay life" section of mainstream magazines such as TimeOut Moscow and Afisha. Even the most successful establishments were not visibly signposted or recognizable as "queer" from the outside, however: for example, the gay and lesbian club 12 Volts, one of the oldest in Moscow, was situated just off the central Tverskaia Street; the main entrance was from a courtyard at the back, where only a tiny plaque with a rainbow flag revealed it was a gay venue, while on the intercom on Tverskaia Street (the other entrance) it was simply listed as "Club 12 Volts." The decision to not make commercial venues too visibly "queer" may have been partly dictated by concerns about patrons' safety, as some clubs advised patrons to stay until closing time (6 A.M.) in order to avoid gay bashing. The low visibility of Moscow-based LGBT community organizations and initiatives is exemplified by the Lesbian and Gay Archive. The archive was based in a private flat, as lack of funding made it impossible to hire separate premises, and the collection was open to the public once a week. Only the telephone number was publicized in the local LGBT media; its exact location (in northwest Moscow) was disclosed to new visitors via phone, and the most common way to find out about the archive was to be told about it and brought there by people already "in the know." Indeed, all community initiatives generally had a low public profile and focused on com- 
munity building through the organization of leisure activities and the provision of support and advice on "everyday" issues. Unlike well-funded and professionalized western LGBT charities focusing on lobbying for equal rights, Moscow-based organizations did not actively seek public visibility or pursue an openly political agenda. To some extent this focus reflected a lack of resources: these initiatives were largely self-funded and received no endorsement or financial support from the local authorities, relied mainly on the work of activists and volunteers, and often shared their premises with other charities or commercial organizations. But keeping a low profile also emerged as a deliberate strategy to avoid confrontation and attracting too much attention: for example, all prominent activists used pseudonyms instead of their full names, and some of the Moscow-based initiatives lacked official registration, which in at least one case was denied by the local authorities, as members of the lesbian association Svoi (Our People) were repeatedly asked to remove the word lesbian from their statute as a condition for registration. ${ }^{36}$

The low visibility of queer space in Moscow does not mean that it was necessarily confined to private settings and hidden from public view. Some of Moscow's more informal queer spaces were, on the contrary, very public, as well-known meeting places for both men and women were located on the open street. Kitai-Gorod was known to be a cruising area for gay men, while young lesbian women met and socialized on the stretch of Tverskoi Bul'var near the monument to Sergei Esenin, a place known in the lesbian community as the Pushka. ${ }^{37}$ At the time when my fieldwork took place the tusovka gathering at the Esenin monument was, to the observant eye, very visible as a lesbian one: girls sporting crew cuts and unisex clothing met to drink, chat, and find a date and seemed unconcerned by the reaction of passers-by, occasionally kissing and making playful reference to lesbian sex; the local press had featured articles revealing that the Pushka hosted a lesbian tusovka, and to some extent the existence of the Pushka was an open secret. ${ }^{38}$ The appropriation of this very public location as "lesbian space" was temporary and spontaneous, however, and may have been completely lost to the unattentive or untrained eye of passers-by, who may not have registered the difference between the group of young women gathering at the Esenin monument and the many other youth tusovki in the area. The lesbian tusovka welcomed this ambiguity, for it allowed members to police group boundaries and reject random intruders. ${ }^{39}$ Thus, even when queer space was extremely public, it was still not immediately visible or recognizable as "queer."

36. Lena B., interview, Moscow, 5 September 2005.

37. Outside the lesbian communuity, the colloquial term Pushka refers more generally to a broader area near Pushkin Square, comprising parts of Tverskoi and Strastnoi Boulevards. This is a popular meeting place for all sorts of youth tusovki and for Muscovites in general (see, for example, Hilary Pilkington, Russia's Youth and Its Culture [London, 1994]).

38. See Elena Minorskaia, "Shakh i Mat Patriarkhatu: Otkroveniia Novykh Amazonok," Medved' 3, no. 12 (2004), at www.lesbiru.com/society/press/medved.html (accessed 9 March 2005; no longer available); Elena Krongauz, "Chelovek s bul'vara," Bol'shoi gorod, no. 16 (142) (28 September-11 October 2005): 26-31.

39. Katja Sarajeva, Lesbian Lives: Sexuality, Space and Subculture in Moscow (Stockholm, 2011). 
The discreet presence of queer space in the city landscape is not exclusive to Moscow..$^{40}$ Yet literature on queer cosmopolitanism tends to focus on territorially bound, visible, and recognizable "gay villages." By contrast, the Moscow scene is neither territorially concentrated nor immediately visible. ${ }^{41}$ Indeed, visibility was not necessarily sought after, and a degree of privacy was welcomed and even actively cultivated by commercial establishments, community initiatives, and informal groups alike.

\section{Nationalism, Cosmopolitanism, and the Politics of Pride and Shame}

\section{Prologue}

On 28 July 2005 Nikolai Alekseev, the leader of the newly established LGBT organization GayRussia.ru, held a press conference to announce their intention to apply for permission to organize the first ever gay Pride festival in the Russian capital. ${ }^{42}$ The event was scheduled for 27 May 2006, to mark the thirteenth anniversary of the repeal of Soviet-era legislation criminalizing consensual sex between adult men. Moscow Pride was organized as a festival, which would feature a conference with guests and activists from abroad and a series of social and recreational events, as well as a march in central Moscow. Alekseev noted that similar events were taking place all over the world, and most recently they had begun to be organized in other postsocialist cities, from Tallin to Sofia; in spite of being the most populous city, however, Moscow remained one of the very few European capitals not to have held such a celebration. ${ }^{43}$ Moscow Pride was therefore presented as an event that would contribute to repositioning Moscow as a truly global, modern, and cosmopolitan city, symbolically distancing it from its socialist past.

The press conference immediately elicited hostile comments from City Hall, which had banned a previous attempt to organize a Pride event in 2001. Moreover, Mayor Iurii Luzhkov's homophobic views were well known. Although the organizers were allowed to hold the conference and the cultural initiatives they had planned, permission to march in central Moscow was repeatedly denied, despite international pressure. Domestically, though, City Hall received significant support, and condemnation of the march by prominent politicians and religious leaders was widespread. ${ }^{44}$ Perhaps predictably, then, the first unauthorized Pride march ended in violence, as queer activists were met by scores of anti-Pride protesters from Orthodox Christian and right-wing nationalist groups, and the police intervened to break up Moscow Pride and arrest demonstrators on both sides..$^{45}$ In subsequent years, Moscow Pride was organized as a march, and no longer as a festival; Moscow City Hall

40. Michael P. Brown, Closet Space: Geographies of Metaphor from the Body to the Globe (London, 2000).

41. Binnie, Globalization of Sexuality.

42. "First Ever Gay Pride to Be Held in Moscow in May 2006," at www.gayrussia.ru/ en/actions/detail.php?ID=1630 (accessed 31 January 2010; no longer available).

43. Ibid.

44. Human Rights Watch, "Pride and Violence: A Chronicle of the Events of May 27, 2006 in Moscow," Human Rights Watch briefing paper, 1 June 2006.

45. Ibid. 
refused to authorize the march each time, even after a new mayor, Sergei Sobianin, was installed in $2010 .{ }^{46}$ And anti-gay violence again marred unsanctioned demonstrations in 2007, 2008, and 2012.47

Moscow Pride changed the articulation of queer space in the capital in important ways. First, it represented an overtly political and very visible claim to public space, quite unlike any of the initiatives previously organized. LGBT cultural festivals, such as the Festival of Lesbian Art and the Festival of Women's Songs, have taken place in the capital since the late 1990s, and in this respect Moscow Pride was by no means new; however, the idea of staging a much publicized, political, and visible march in central Moscow was novel, as previous festivals and community events had a social and recreational, rather than overtly political character, and the organizers deliberately avoided attracting attention through media exposure. For example, Lena B., leader of the grassroots lesbian group Klub Svobodnogo Poseshcheniia, regularly organized in the early 2000s a cruise on the Moscow River called "Rainbow over Moscow" that was conceived as a social outing with a political message: participants waved rainbow flags from a rented boat as the boat passed the Kremlin. Although the event symbolically gestured toward public visibility, its claim was deliberately understated; the rainbow flags were used primarily for the benefit of the participants rather than to draw public attention to the issue of gay rights. ${ }^{48} \mathrm{~A}$ second and related point is that the "Pride march that never was" gave the community it purported to represent unprecedented media exposure, both nationally and internationally, as Pride organizers actively sought to publicize the event, using visibility as a political strategy and as a way to mobilize support. Strategies based on claims to visibility and recognition proved very controversial and divisive among the Moscow LGBT community, however, and ultimately had the paradoxical effect of putting the Russian capital in the spotlight as the most un-gay-friendly city in Europe, as Moscow Pride was met with hostility and violence.

\section{Moscow as a National Battleground for LGBT Rights}

The controversies surrounding Moscow Pride turned the capital into a symbolic battleground for sexual citizenship rights in Russia. The confrontation, however, was as much about rights as about visibility and symbolic claims to public space: indeed, while the lectures and debates organized for the 2006 Moscow Pride Festival went ahead as planned in semipublic indoor premises, the Pride march, which was meant to conclude the three-day festival, was categorically banned. ${ }^{49}$ It is significant that the organizers had asked for

46. Aleksei Druzhinin, "Moscow Mayor Pledges No Gay Pride Parades on His Watch," RIA Novosti, 24 November 2011, at en.ria.ru/society/20111124/169012089.html (last accessed 31 May 2013).

47. Moskovskaia Khel'sinkskaia Gruppa, Polozhenie lesbiinok, geev, biseksualov, transgenderov $v$ Rossiiskoi Federatsii (Moscow, 2009), at www.mhg.ru/files/009/lgbt.pdf (last accessed 31 May 2013); Amnesty International, "Russia: Moscow Must End 'Shameful' Clampdown on Pride," 28 May 2012, at www.amnesty.org/en/news/russia-moscowmust-end-shameful-clampdown-pride-2012-05-28 (last accessed 31 May 2013).

48. Lena B., interview, Moscow, 5 September 2005.

49. Human Rights Watch, "Pride and Violence." 
permission to hold the first Pride march in the very heart of Moscow, along Tverskaia Street, the main radial thoroughfare in central Moscow leading to the monumental Kremlin complex. The location was chosen for its symbolic importance and to maximize visibility, but the area has traditionally been used to stage official rallies, such as the Victory Day military parade, rather than as a site of street protests and civil society demonstrations. Moreover, since the mid-1990s the city administration had invested the area with a specific symbolic meaning, conspicuously allocating resources to revitalize this district and turn it into a symbol of national identity and tradition. ${ }^{50}$

Traffic disruptions, the potential for clashes between gay activists and groups opposing the event, and the inability to guarantee public security were initially offered as the main reasons for banning the event by Moscow City Hall officials. ${ }^{51}$ But the tone of the debate was set by Mayor Luzhkov, who, on the eve of the first Pride march, stated:

As long as I am mayor, we will not permit such parades. Our church, mosque, and synagogue-that is to say, all the three major confessions in Moscowhave spoken strongly against such parades. [. . .] The situation as such can be acceptable for some western countries [. . .] but it is absolutely unacceptable for Moscow and for Russia. Morality works here. If anyone has any deviations from normal principles in organizing one's sexual life, those deviations should not be exhibited for all to see, and those who may turn out unsteady should not be invited to do so. [...] I thank the citizens of Moscow as 99.9 percent of them in recent days also believe it is unacceptable to hold such parades. ${ }^{52}$

Luzhkov's incendiary remarks made it clear that the ban on Moscow Pride reflected a stance on the public visibility of homosexuality in Russian society. This was confirmed in a memorandum issued by deputy Mayor Liudmila Shestova, which stated that, although, unlike during the Soviet period, same-sex relations were no longer forbidden by law, the public celebration of homosexuality through gay festivals and parades promoted immorality, and for this reason local authorities were entitled to ban such initiatives. ${ }^{53}$

By invoking public morals and the values of the (heterosexual) majority, as well as the moral authority of the city's three major faith communities, Luzhkov promoted the image of Moscow as a heterosexual city, where sexual diversity can at best be tolerated in private but not publicly celebrated. Luzhkov also consistently deployed nationalist rhetoric to justify the ban, by pitting Russian national traditions and morals against western customs. When international human rights and LGBT organizations, as well as politicians

50. Benjamin Forest and Juliet Johnson, "Unravelling the Threads of History: SovietEra Monuments and Post-Soviet National Identity in Moscow," Annals of the Association of American Geographers 92, no. 3 (September 2002): 524-27; Graeme Gill, "Changing Symbols: The Renovation of Moscow Place Names," Russian Review 64, no. 3 (July 2005): 480-503.

51. Patrick Jackson, "Gay Pride Challenges Moscow," BBC News, 17 February 2006, at news.bbc.co.uk/2/hi/europe/4714818.stm (last accessed 31 May 2013).

52. "Luzhkov: As Long as I Am Mayor There Will Be No Gay Parades in Moscow," Interfax, 26 May 2006, at www.interfax-religion.com/?act=news\&div=1484 (last accessed 31 May 2013).

53. Human Rights Watch, "Pride and Violence," 3. 
and celebrities from western Europe and North America, tried to put pressure on the Moscow administration to lift the ban, Luzhkov refused to yield to these pressures and accused the west of trying to force its liberal values on Russia, corrupting its unique morals and traditions. ${ }^{54}$ Luzhkov's narrative constructed Moscow, the national capital, as the bastion of Russian tradition, which had to be protected against the pernicious western influences brought by cultural globalization, rather than as a global city working to establish a multicultural and cosmopolitan image.

In the run-up to the first march in 2006, hostile views on Moscow Pride dominated the media debates, as Luzhkov's argument that it would go against Muscovite and, by extension, Russian moral values and traditions, was also voiced by deputies of the Moscow Duma and by the leaders of Orthodox Christian, Muslim, and Jewish faith communities..$^{55}$ The rhetoric deployed by those opposing the march operated not only on a symbolic level to reinforce the assumed division between the righteous majority and the "deviant" queer minority: it also influenced how events unfolded. During the 2006, 2007, and 2012 unsanctioned Pride marches, gay activists were outnumbered by riot police and scores of protesters from Orthodox Christian and far-right nationalist groups, chanting homophobic abuse and slogans such as "Moscow is not Sodom." ${ }^{.56}$ Gay activists and their supporters were physically attacked by farright hooligans, initially undisturbed by the riot police, who seemed to collude with the groups and the violent individuals opposing Moscow Pride. The unsanctioned Pride marches of 2008, 2009, 2010, and 2011 again highlighted public opposition to the march and the marginalization of gay activists. ${ }^{57}$ Direct confrontations between supporters of GayRussia and their opponents were avoided, as the march took place in a secret location disclosed only to a few queer activists, rather than in the place originally advertised, in order to avoid both the riot police and the anti-Pride demonstrators who had gathered there. Parallel street gatherings organized by anti-Pride protestors took place simultaneously, however, albeit in different locations from the Pride march. The police immediately intervened to arrest queer activists, while showing a more lenient approach to anti-Pride demonstrators, who were arrested only if they turned violent, although anti-Pride gatherings had not been officially 2007.

54. Carl Schreck, "Luzhkov Says Gay Pride Is 'Satanic," Moscow Times, 30 January

55. Mikhail Pozdiaev, “'Vyidut-budem lupit'!' Muftii Tadzhuddin gotovitsia dat' otpor uchastnikam gei-parada v Moskve," Novye izvestiia, 15 February 2006; Jackson, "Gay Pride Challenges Moscow."

56. Jackson, "Gay Pride Challenges Moscow."

57. Iurii Timofeev, "Gei-parad v Moskve: Fotoreportazh," 1 June 2008, at www. svobodanews.ru/content/article/450119.html (last accessed 31 May 2013); Aleksandr Nechaev and Aleksei Obchinnikov, "Na gei-parade v Moskve militsionery zaderzhali 10 inostrantsev," Komsomol'skaia pravda, 16 May 2009, at www.kp.ru/daily/24294/488937/ (last accessed 31 May 2013); Evgeniia Suprycheva, "V Moskve proshel samyi masshtabnyi gei-parad za poslednye 5 let," Komsomol'skaia pravda, 29 May 2010, at kp.ru/ daily/24498/651843/ (last accessed 31 May 2013); Anastasiia Berseneva, "Geev ne pustili k Vechnomu ogniu: V Moskve razognan gei-parad, 40 zaderzhannykh," gazeta.ru, 28 May 2011, at www.gazeta.ru/social/2011/05/28/3631965.shtml (last accessed 31 May 2013). 
sanctioned either. ${ }^{58}$ The institutional prejudice of Moscow City Hall officials was clearly reflected in the double standards deployed by riot police in dealing with Pride marchers and their opponents.

As opposition to Moscow Pride was endorsed and fueled by political and religious authorities, the event failed to symbolically reclaim Moscow city center space as queer and to publicly affirm and celebrate sexual diversity. On the contrary, each Pride march was symbolically turned into a very graphic public shaming of the LGBT community, and into a display of nationalist pride, with police forces and anti-Pride demonstrators outnumbering the gay activists. As religious icons, crosses, and headscarves were displayed by anti-Pride demonstrators to defend the city as "truly Russian," echoing the nationalist rhetoric deployed by Luzhkov, what remained for all to see were the emblems of institutional authority and the symbols of Russian tradition turned against the gay activists.

\section{Queer Activism, Visibility, and the "National Interest"}

Moscow Pride and the conflicts it engendered have to be understood within a broader political context characterized by the progressive descent of Vladimir Putin's "managed democracy" into a new brand of authoritarian and statist nationalism. ${ }^{59}$ Particularly since the introduction of new legislation regulating the work of NGOs in 2006, state authorities have stifled political opposition and genuine pluralism and often clamped down on street demonstrations organized by opposition parties and social movements..$^{60}$ Limitations on freedom of expression, association, and assembly aimed at the activities of LGBT organizations are by no means a new phenomenon. ${ }^{61}$ Other NGOs and grassroots groups, however, have experienced similar problems, particularly since the mid-2000s.

The Russian government has actively sought to control and co-opt civil society by imposing stricter regulations on their registration and offering support to selected voluntary sector organizations. ${ }^{62}$ The new legislation and

58. The only exception was the 2010 march, held on Leningradskoe Shosse, on the outskirts of Moscow; on this occasion the riot police did not intervene to disperse gay activists; see Suprycheva, "V Moskve proshel samyi masshtabnyi gei-parad za poslednye 5 let."

59. Igor Torbakov, "Russia: Looking at Putin's Nationalist Dilemma," Eurasianet.org, 8 February 2012, at www.eurasianet.org/node/64975 (last accessed 31 May 2013).

60. Amnesty International, Russian Federation: Freedom Limited-The Right to Freedom of Expression in The Russian Federation (26 February 2008), at www.amnesty.org/en/ library/info/EUR46/008/2008 (last accessed 31 May 2013); Graeme B. Robertson, "Managing Society: Protest, Civil Society, and Regime in Putin's Russia" Slavic Review 68, no. 3 (Fall 2009): 528-47.

61. Under Mayor Luzhkov (1992-2010), the Moscow administration refused official registration to at least two LGBT organizations, including the lesbian association Svoi, mentioned above, and the LGBT umbrella organization Treugol'nik in the 1990s. See Essig, Queer in Russia.

62. Robertson, "Managing Society"; Alfred B. Evans Jr., "Russian Society and the State," in Stephen White, Richard Sakwa, and Harry E. Hale, eds., Developments in Russian Politics 7 (Durham, 2010). 
policies on the voluntary sector that Putin initiated were based on the premise that Russia needed a strong civil society in order to thrive but that the relationship between nongovernmental organizations and the state should be nonantagonistic and cooperative. The law sets narrow limits on permissible conflict between civil society and the state: legislation on social organizations approved by the Duma in 2005 makes it possible to ban any organization that threatens "Russia's sovereignty, independence, territorial integrity, national unity and originality, cultural heritage and national interests." ${ }^{\circ 3}$ The selective endorsement of civil society groups was couched in terms of national identity, national interest, and national security; as in the public realm, private interests should be subordinate to the collective interest of the nation. ${ }^{64}$ The new legislation and the financial resources made available for voluntary sector organizations were also aimed at reducing western influence on Russian civil society, amid concerns that western-funded associations may support activities detrimental to the national interest or undermine the Russian government. ${ }^{65}$ Unsurprisingly, these policies have resulted in the "strengthening of groups with a nonpolitical or pro-state orientation and the isolation of more adversarial groups or organizations." 66

Nationalist and far right-wing organizations generally benefited from the state's selective endorsement of civil society groups. The ideological closeness between the political authorities and far-right nationalist organizations have created opportunities for the latter, giving them enhanced visibility and a degree of legitimacy, as "President Putin's systematic appeal to the image of strong Russia, to Orthodox symbols, militarist rhetoric [. . . ] creates a demand from the top for nationalism in society."67 LGBT community organizations, on the other hand, fall into the category of the oppositional groups whose activities the government is keen to limit, often in the name of national interest. When asked about his attitude to gay rights a few months after the first controversial Moscow Pride festival, President Putin stated: "My attitude to gay pride parades and sexual minorities is simple, and it is linked to the fulfilment of my official duties: one of the country's greatest problems is the demographic crisis." 68

Putin's comments imply that any public endorsement or recognition of "sexual minorities" would be detrimental to the national interest, as mounting concerns over the country's demographic crisis and declining birthrate turned pro-natalist and pro-family policies into a key national priority. ${ }^{69}$ The

63. Evans, "Russian Society and the State," 102.

64. Ibid.

65. Amnesty International, Russian Federation: Freedom Limited.

66. Robertson, "Managing Society," 531.

67. Mihai Varga, "How Political Opportunities Strengthen the Far-Right: Understanding the Rise in Far-Right Militancy in Russia," Europe-Asia Studies 60, no. 4 (June 2008): 576.

68. "Prezident Rossii Vladimir Putin s uvazheniem otnositsia $\mathrm{k}$ seksual'nym men'shinstvam," Gay.ru,1 February 2007, atwww.gay.ru/news/rainbow/2007/02/01-9224. htm (last accessed 31 May 2013).

69. Anna Rotkirch, Anna Temkina, and Elena Zdravomyslova, "Who Helps the Degraded Housewife? Comments on Vladimir Putin's Demographic Speech," European Journal of Women's Studies 14, no. 4 (November 2007): 349-57. 
argument that same-sex relations do not contribute to the reproduction of the nation, an essential duty of every good citizen, was used to justify restrictions on public expressions of nonheteronormative sexuality, for this is perceived as a potential threat to the existing social order. Indeed, in the debate on the demographic crisis, low birthrates were attributed to the country's declining moral values and loose sexual mores, both often attributed to western cultural influence. ${ }^{70}$ Such arguments continued to be deployed to oppose sexual health education and to limit women's choices on reproductive issues. With the launch of a national program to halt the demographic crisis, the Russian government has consistently used a rhetoric that exalts the value of motherhood and the nuclear family while devaluing nonreproductive sex and portraying the increased visibility of homosexuality in Russian society as the result of western influence. ${ }^{71}$

\section{Sexual Cosmopolitanism and Its Discontents: National and International Solidarities}

Although Moscow Pride has received ample media coverage both within Russia and abroad, reports often overlook the fact that the event proved divisive among the local LGBT community, despite attracting substantial international solidarity. Support and opposition to Moscow Pride, and the involvement-or lack thereof-of local, national, and global actors, invite a reflection on the strategic uses of visibility and of human rights discourses by organizers of the event and more broadly on the tensions between the local and the global in cosmopolitan sexual politics. ${ }^{72}$ Indeed, Moscow Pride and, more broadly, the political strategies used by its organizer GayRussia are an eminently cosmopolitan project, inspired by ideals of "sexual democracy" and by the desire to engage with a wider, global LGBT movement. ${ }^{73}$ GayRussia was founded in May 2005 as a human rights project. ${ }^{74}$ By making campaigns for human rights, equality, recognition, and visibility central to its activities, GayRussia claimed a place within an increasingly global LGBT movement. ${ }^{75}$ While attracting huge support from abroad, however, Moscow Pride largely failed to secure meaningful support from local LGBT community initiatives, or from other Russian civil society organizations. ${ }^{76}$

70. Rivkin-Fish, "From 'Demographic Crisis' to 'Dying Nation”"; Dan Healey, “'Untraditional Sex' and the 'Simple Russian': Nostalgia for Soviet Innocence in the Polemics of Dilia Enikeeva," in Thomas Lahusen and Peter H. Solomon Jr., eds., What Is Soviet Now? Identities, Legacies, Memories (Berlin, 2008), 173-91.

71. Rivkin-Fish, "From 'Demographic Crisis' to 'Dying Nation."”

72. Kendall, Woodward, and Skrbiš, Sociology of Cosmopolitanism; Mendieta, "From Imperial to Dialogic Cosmopolitanism?"241-58.

73. Éric Fassin, "National Identities and Transnational Intimacies: Sexual Democracy and the Politics of Immigration in Europe," Public Culture 22, no. 3 (Fall 2010): 507-29.

74. "Russian LGBT Human Rights Project," at www.facebook.com/pages/RussianLGBT-Human-Rights-ProjectGayRussiaRu/150886698292823; see also www.gayrussia. eu/about-us/ (last accessed 31 May 2013).

75. Manon Tremblay, David Paternotte, and Carol Johnson, The Lesbian and Gay Movement and the State (Farnham, Eng., 2011).

76. Stella, “The Right to Be Different?”; Sarajeva, Lesbian Lives. 
In a 2005 radio debate, held just weeks after plans to stage the Moscow Pride Festival were announced, Alekseev, GayRussia's leader, explained the aims of the event: "The meaning of this event is to show that gay people exist, that they are people like everyone else, and that they have the right to express their opinion. It will help [gay] people understand that they are not alone, that they belong to a group of people, and that is the most important thing. They will be able to understand that they are not dealing with their problems on their own, and that although the state is not dealing with them, they can force the state to solve them."77

Yet despite Alekseev's intensions, GayRussia failed to secure the support of other Moscow-based LGBT community organizations and initiatives. Many representatives of more established community projects expressed reservations about GayRussia, a brand-new organization whose leaders had little previous involvement in local community initiatives.$^{78}$ More important, leaders of other Moscow-based LGBT organizations were highly critical of the idea of staging a very public Pride march in central Moscow, fearing that the event would be perceived as a provocation in the Russian context and result in a backlash against the LGBT community; in addition, they voiced concerns about the safety of participants. Some activists signed a joint letter to ILGAEurope (European Region of the International Lesbian and Gay Association) to dissociate themselves from the event and joined forces to organize an alternative festival of gay and lesbian culture called Rainbow without Boundaries, which was held at an indoor venue a few weeks before the 2006 Moscow Pride march. ${ }^{79}$ The events that followed seemed to confirm their worst fears that increased visibility would make the LGBT community an easy target of violence: both the alternative festival and the actual Moscow Pride march were targeted by violent youths from far-right groups. ${ }^{80}$

The Moscow Pride march itself attracted only a few dozen participants each year, despite Alekseev's expectation that 2,000 would participate in 2006, a fact that partly reflects the climate of intimidation and partly results from the secrecy around the exact location of the march. ${ }^{81}$ Paradoxically for an event that was meant to be a rallying call for the Russian LGBT community, a very substantial number of participants were foreign representatives from international human rights and LGBT organizations and politicians from western Europe, particularly in 2006 and 2007.82 Addressing an international audience rather than the local LGBT community and ensuring maximum media exposure seemed to be a deliberate strategy that reflected GayRussia's

77. "Ishchem vykhod ... Sostoitsia gei-parad v Moskve?" (2 August 2005), at echo. msk.ru/programs/exit/37908/ (last accessed 31 May 2013).

78. Stella, "The Right to Be Different?"; Sarajeva, Lesbian Lives.

79. Sarajeva, Lesbian Lives.

80. Human Rights Watch, "Pride and Violence."

81. "Ishchem vykhod ... Sostoitsia gei-parad v Moskve?"

82. Human Rights Watch, "Pride and Violence"; Human Rights Watch and the European Region of the International Lesbian and Gay Association, “We Have the Upper Hand': Freedom of Assembly in Russia and the Human Rights of Lesbian, Gay, Bisexual, and Transgender People," 13 June 2007, at www.hrw.org/en/reports/2007/06/13/we-haveupper-hand (last accessed 31 May 2013). 
cosmopolitan orientation. Indeed, the involvement of high-profile foreign guests ensured wide coverage both in the Russian media and abroad, turning Moscow Pride into a media event of epic proportions, in spite of very limited participation on the ground.$^{83}$ It is not surprising that the strategies deployed by GayRussia were initially well received internationally, as they spoke the familiar language of visibility, recognition, and human rights rooted in the western tradition of LGBT activism; agendas that resonate with this tradition may be very far from the priorities of local grassroots organizations, however, as previous research on the role of western aid in supporting the development of Russian civil society shows. ${ }^{84}$ In an article published on the British broadsheet The Guardian and on several LGBT information Web sites across the world after the 2009 Pride, Alekseev stated: "Slowly, we are eroding homophobic attitudes. Through this media visibility, we are helping to normalise queer existence. After our successive gay protests in Moscow since 2006, people are less shocked about homosexuality. We have a long way to go, but gradually we are winning hearts and minds, especially among younger Russians." 85

U.K.-based campaigner Peter Tatchell, the author of the article and a participant in Moscow Pride for several years, approvingly commented on the strategies deployed by the organizers, adding: "The gay parade organisers realise that the conferences, glossy reports and low-key vigils of other Russian and international gay organizations have little or no impact on the government-or on public consciousness. It is only visible and challenging actions, like the gay parades, that put queer issues on the public and political agenda." 86

While it is difficult to gauge the overall impact of Moscow Pride, recent developments give few causes for optimism about its success in "changing hearts and minds." A poll from early 2012 conducted by Vserossiiskii tsentr izucheniia obshchestvennogo mneniia (VTsIOM, All-Russian Center for the Study of Public Opinion) showed that almost 90 percent of Russians would support the introduction of a law banning the "propaganda of homosexuality," although only 6 percent had actually come across such a phenomenon; the latter figure rose to 14 percent for residents of Moscow and St. Petersburg, traditionally considered the most progressive and "gay-friendly" Russian cities. $^{87}$

In the near absence of domestic support, GayRussia seemed to rely mainly on the international community to exercise pressure on the Russian state to improve its record on LGBT rights. Yet high-profile international support on

83. In 2006 and 2007 high-profile participants from abroad included Scott Long from the U.S.-based organization Human Rights Watch, U.K.-based gay rights activist Peter Tatchell, and the openly gay German member of parliament Volker Beck.

84. Julie Hemment, "The Riddle of the Third Sector: Civil Society, Western Aid, and NGOs in Russia," Anthropological Quarterly 77, no. 2 (Spring 2004): 215-41.

85. Peter Tatchell, "Thank You Mayor Luzhkov," The Guardian, 19 May 2009, at www. guardian.co.uk/commentisfree/2009/may/19/russia-gay-pride-luzhkov (last accessed 31 May 2013).

86. Ibid.

87. "Zakon o 'muzhelozhstve i lesbiianstve' idet v Moskvu," Interfax, 19 April 2012, at www.interfax.ru/society/txt.asp?id=241810 (last accessed 31 May 2013). 
the ground dwindled over the years, and by 2009 the majority of the participants in Moscow Pride were Russian, supported by a Belorussian partner organization..$^{88}$ By this stage, though, Moscow Pride had acquired an international platform to shame the Moscow authorities and the Russian government for their treatment of gay activists and the violation of their right to assembly and expression. Moreover, GayRussia appealed in court Moscow City Hall's decision to repeatedly ban Pride marches and pickets in the capital; as domestic courts repeatedly dismissed the case, it eventually reached the European Court of Human Rights. ${ }^{89}$ Strategies based on claims to formal equality and visibility and the shaming of national governments for their LGBT rights record have been successful in other postsocialist states, where governments have given in to international pressure and introduced gay-positive legal changes to comply with European Union or Council of Europe requirements, in spite of vocal opposition from mainstream political parties and the general public. ${ }^{90}$ Given Russia's marginal position within the "new" Europe and its worsening relations with both western European and former Soviet bloc countries, however, intimations from European institutions are likely to have little impact. A case in point is the outcome of the case Alekseyev v. Russia at the European Court of Human Rights: even though in 2010 the court ruled in favor of Alekseev, who received financial compensation from the Russian government, GayRussia activists were still denied permission to hold a Pride march in the following years. ${ }^{91}$ In the Russian context, the effectiveness of sexual politics that hinge on visibility, international solidarities, and naming and shaming strategies is at best uncertain and at worst counterproductive. Indeed, GayRussia's reliance on pressure from the international community may unwittingly have reinforced the association between global LGBT politics and perceived western cultural imperialism, already prominent in nationalist discourses.

Whatever the merits of Moscow Pride, its greatest limitations lie in its failure to meaningfully engage with the Moscow and national LGBT community and to build bridges with other civil society organizations within Russia.

88. For international groups, the focus shifted from Moscow Pride to other initiatives. In 2009 ILGA-Europe launched a program designed to build capacities for Russian LGBT organizations centered around community networks in St. Petersburg (main hub), Petrozavodsk, Tiumen', and Moscow; GayRussia was not listed among the project's partner institutions. See "Empowerment and Capacity Building of Russian LGBT Organisations," at ilga-europe.org/home/how_we_work/developing/projects/russian_project (last accessed 31 May 2013).

89. Paul Johnson, "Homosexuality, Freedom of Assembly and the Margin of Appreciation Doctrine of the European Court of Human Rights: Alekseyev v. Russia," Human Rights Law Review 11, no. 3 (September 2011): 578-93.

90. Darja Davydova, "Baltic Pride 2010: Articulating Sexual Difference and Heteronormative Nationalism in Contemporary Lithuania," Sextures 2, no. 2 (2012): 32-46; Carl Stychin, Governing Sexuality: The Changing Politics of Citizenship and Law Reform (Oxford, 2003).

91. Johnson, "Homosexuality, Freedom of Assembly and the Margin of Appreciation Doctrine of the European Court of Human Rights"; "Gay Parades Banned in Moscow for 100 Years," BBC News Europe, 17 August 2012, at www.bbc.co.uk/news/world-europe19293465 (last accessed 31 May 2013). 
Paradoxically, GayRussia's reliance on the international community as the arbiter of equality and social justice seems to mirror Luzhkov's narrative in reverse, by emphasizing the moral superiority of the global and cosmopolitan against the national and the local, while failing to create meaningful dialogue between these dimensions. The danger here is that GayRussia's sexual cosmopolitanism may appear as an abstract and normative value, only tenuously related to local realities and aspirations, and therefore contribute to a polarization of positions, ultimately playing into the hands of authoritarian and sexually conservative nationalist discourses.

While the presence of queer space in Moscow had traditionally been discreet and hidden, Moscow Pride radically changed the articulation of queer space in the city by claiming a visible queer presence in public space and by investing queer visibility with a political meaning. The analysis presented here contextualizes the reactions to Moscow Pride within a national framework characterized by the stifling of oppositional movements and the rise of an antiwestern and sexually conservative brand of nationalism in Russia. The organization of Moscow Pride is read, not as a sign of progressive global politics and acceptance of sexual diversity, but as an open-ended signifier whose local interpretation is ultimately dependent on the wider sociopolitical context.

The hostile reception of Moscow Pride highlights the importance of considering how sexuality is deployed in the construction of normative and exclusionary notions of national identity in today's Russia, a theme explored in sexuality studies but often overlooked in broader analyses of Russian nationalisms..$^{92}$ This angle can provide important insights, especially as the controversies surrounding the activities and punishment of the feminist punk band Pussy Riot show that sexual rights and freedoms have become hotly contested sites of political struggle, both from above and from below. Despite the lack of domestic support for Moscow Pride described in the article, the diverse forces coalescing around the anti-Putin oppositional movement may create new synergies around sexual citizenship activism in Russia: for example, a recent demonstration organized by the anti-Putin opposition in Moscow, which attracted an estimated 20,000 participants, featured a contingent from the LGBT community, as well as supporters of the jailed Pussy Riot members..$^{93}$

Beyond the Russian context, Moscow Pride's failure to reclaim Moscow city center as queer, however, also invites a critical reflection on the contextual ability of strategies based on visibility, recognition, and human rights to pursue cosmopolitan values of openness and respect toward sexual diversity. The literature on urbanism and queer space has contributed important insights about the role of visible gay enclaves and Pride parades in constructing cities as cosmopolitan and global, highlighting how visibility is essential in constituting queer communities as a political subject. The notion of visibility

92. Marlène Laruelle, ed., Russian Nationalism and the National Reassertion of Russia (Abingdon, Eng., 2009).

93. Marsh Millionov: Onlain-Reportazh, Radio Svoboda, 16 September 2012, at www. svoboda.org/content/article/24708540.html (last accessed 31 May 2013). 
as empowering and enabling is problematic in the Russian context, however. The outcome of Moscow Pride illustrates how, in a context characterized by state-endorsed homophobia, a hostile local government, and the rise of authoritarian politics in the country, visibility can incite danger, alienate LGBT constituencies, and fail to attract support from the broader civil society, while exposing queer activists to very public displays of victimization and shaming. Moscow Pride also illustrates the risks involved in invoking sexual cosmopolitanism by relying heavily on the support of transnational solidarity networks and by privileging global over local civil society as an interlocutor. While ensuring international media visibility, this approach assumes that the international community can effectively act as the arbiter of sexual citizenship globally, failing to acknowledge the contradictory and unequal power relations that govern the global politics of human rights. Indeed, "sexual democracy" has been invoked as a European or western value, acquiring a normative, ethnocentric connotation and fueling a new brand of xenophobic sexual nationalism within the west itself, whereby LGBT rights are taken as a measure of a country's successful development and modernization and are discursively deployed to racialize foreign nations and migrant communities. ${ }^{94}$ These points echo Eduardo Mendieta's perceptive discussion of the tensions between the global and the local in the cosmopolitan ideal, and the need to recognize the power of locality, since "one is never cosmopolitan without setting out from some locality, whether it be spatial or temporal." Mendieta argues against a normative, "imperial" cosmopolitan disposition, "blind or dismissive of its own material conditions of possibility," while calling for a rooted, reflexive cosmopolitanism, firmly grounded in local realities and better able to open up spaces for dialogue by engaging simultaneously with local, national, and transnational actors and by couching its demands in terms of a relativistic and contextual universalism..$^{95}$ Thus, unlike the flow of goods and capital, a cosmopolitan openness toward the sexual "other" is not the inevitable product of globalizing processes, as recent research on transnational sexual politics shows ${ }^{96}$ More locally contextualized research is needed in order to unpack the tensions between the cosmopolitan, the national, and the local in global sexual politics, and research on eastern Europe and the former Soviet Union can provide important insights in this debate, given the postcommunist region's geopolitical position as part of the "new" Europe or as a new borderland of Europe.

94. Fassin, "National Identities and Transnational Intimacies"; Jasbir Puar, Terrorist Assemblages: Homonationalism in Queer Times (Durham, 2007).

95. Mendieta, "From Imperial to Dialogic Cosmopolitanism?" 241-42.

96. Hakan Seckinelgin, "Global Civil Society as Shepherd: Global Sexualities and the Limits of Solidarity from a Distance," Critical Social Policy 32, no. 4 (November 2012): 536-55; Jon Binnie and Christian Klesse, "Researching Transnational Activism around LGBTQ Politics in Central and Eastern Europe: Activist Solidarities and Spatial Imaginings," in Kulpa and Mizielińska, eds., De-Centring Western Sexualities, 107-29. 